\title{
EXPOSURE OF OPERATORS TO CHAINSAW VIBRATION IN FOREST HARVESTING
}

\author{
André Tavares de Jesus ${ }^{1}$; Nilton Cesar Fiedler ${ }^{2 *}$; Flávio Cipriano de Assis do Carmo ${ }^{3}$; Ronie Silva Juvanhol ${ }^{4}$ \\ ${ }^{1}$ Engenheiro Florestal, MSc Ciências Florestais UFES, Secretaria Meio Ambiente Amapá. E-mail: andrejesus80@ gmail.com; \\ ${ }^{2}$ Prof. Titular - Depto Ciências Florestais e da Madeira UFES- E-mail: nilton.fiedler@ufes.br \\ ${ }^{3}$ Prof. Adjunto - Univ. Federal de Campina Grande - Campus Patos. E-mail: flaviocipriano@ @otmail.com; \\ ${ }^{4}$ Prof. Adjunto Univ. Federal do Piauí - Campus Bom Jesus. E-mail: ronie_juvanhol@ hotmail.com
}

Received for publication on: 20/03/2019 - Accepted for publication on: 12/03/2020

\begin{abstract}
Resumo
Exposição à vibração em operadores de motosserra na colheita florestal. O processo de implementação de sistemas semimecanizados ocorrido nas últimas décadas no país trouxe inúmeros benefícios de rentabilidade, qualidade e segurança para as atividades florestais. Entretanto, o uso indevido da motosserra pode causar efeitos nocivos à saúde dos operadores. Entre esses efeitos tem-se o excesso de vibração, responsável por inúmeros distúrbios tais como a síndrome de Raynoud. Desta forma, objetivou-se a partir dessa pesquisa avaliar o grau de exposição dos operadores à vibração da motosserra no corte florestal de eucalipto em propriedades rurais. Para a mensuração dos dados foi utilizado um acelerômetro portátil com medidor de vibração triaxial posicionado nos pontos de encaixe das mãos dos operadores. Para a classificação do grau de exposição, utilizouse a metodologia proposta pela NHO-10. De acordo com os resultados, 55\% dos operadores apresentaram níveis de exposição acima do aceitável, necessitando de intervenções que permitam a diminuição da vibração mão - braço. O ponto de encaixe da mão esquerda dos operadores foi o local que mais se observou os efeitos da vibração. Com base nos resultados obtidos, concluiu-se que há a necessidade de medidas preventivas e corretivas que diminuam a exposição dos operadores como melhorias no projeto das máquinas, rodízio entre operações e maiores cuidados com a manutenção das máquinas utilizadas, treinamento e redução do tempo de exposição.
\end{abstract}

Palavras-Chave: Corte florestal; Ergonomia florestal; Produção Florestal.

\begin{abstract}
The implementation process of mechanized systems which occurred in the last decades in Brazil has brought numerous benefits of profitability, quality and safety for forestry activities. However, mechanization can cause harmful effects to the health of operators, among which include the excess of vibration that is responsible for numerous disorders such as Raynaud's syndrome. The objective of this study was to evaluate the degree of exposure to vibration of chainsaw operators in cutting eucalyptus trees on farms. Thus, a portable accelerometer with a triaxial attachment positioned at the fingers of the operators was used to measure the data. The methodology proposed by NHO-10 was used to classify the degree of exposure. According to the results, 55\% of the operators presented above the acceptable levels of exposure, requiring interventions which enable reduced hand-arm vibration. The vibration effects were observed to be more severe in the left hand socket of the operators. Based on the obtained results, it is concluded that there is a need for preventive and corrective measures which reduce the exposure of the operators as an intervention in the design of the machines, more rotation between operations, and greater care with the maintenance of the machines, training and reduced exposure time.
\end{abstract}

Keywords: Cutting forest; Forest Ergonomic; Production Forests.

\section{INTRODUCTION}

Forest harvesting can be defined as a set of operations carried out in the forest stand which comprises everything from preparation to driving the wood to the place of transport, and using pre-established techniques and standards in order to transform it into a final product (LIMA E LEITE, 2014; SILVA et al., 2010). Forest harvesting operations have reached a high stage of mechanization, but some activities, mainly in small producers, still require semi-mechanized work due to the high cost of acquisition of machines and implements, the low volume of wood moved and limitations due to the slope of the forest ground (MENDES et al, 2019). Chainsaw semimechanized forest cutting is an activity with a high risk of accidents.

However, the mechanization of part or all of forestry operations brought with it the need to deepen studies on what are the negative effects that the machines can cause to the physical and mental health of the forest harvest operators, especially semi-mechanized operations (SANT'ANNA et al., 2000).

One of the effects of using a chainsaw in forest harvesting is the vibration of these machines. According to the Canadian Center for Occupational Safety and Health (CCOHS, 2016), vibration is a perception transmitted to the operator when handling machinery which can be onto the full body or only the hands and arms. Vibration

FLORESTA, Curitiba, PR, v. 50, n. 3, p. 1653 - 1659, jul/set 2020.

Jesus, A. T. et.al.

ISSN eletrônico 1982-4688

DOI: $10.5380 /$ rf.v50 i3. 65530 
comprises any movement that the body performs around a fixed point. This movement can be regular of the sinusoidal type, or irregular when it does not follow any determined pattern (FIEDLER, 2013). The effects of vibration on the operators' bodies can be considered harmful and of great risk to their health. Such effects are directly linked to the intensity and exposure time of operators to vibration.

Among the main effects caused by excessive exposure to vibration are abdominal pain, nausea, chest pain, and loss of balance, in addition to a greater propensity for Raynaud's syndrome, or white finger syndrome, characterized by poor blood circulation in the upper limbs of operators (OTERO et al., 2013; VICENTE; REDONDO, 2015). According to Nunes (2005), mechanical oscillations are transmitted in Hand-Arm Vibration (HAV) which entail risks for the health and safety of workers when transmitted to them, especially vascular disorders, bone-articular injuries and neurological disorders or muscular. Thus, this research aims to verify whether the vibration transmitted to workers during wood cutting results in a health risk.

In this sense, the objective of this work was to evaluate the degree of vibration exposure in chainsaw operators involved in semi-mechanized forest harvesting activities in rural properties in the southern state of Espírito Santo.

\section{MATERIALS AND METHODS}

\section{Characterization of the study area}

The study was carried out in Eucalyptus plantations in the south of the state of Espírito Santo in properties located in the municipalities of: Mimoso do Sul, with coordinates $21^{\circ} 66^{\prime} 8.83^{\prime \prime} \mathrm{S}$ and $41^{\circ} 13^{\prime} 40.62^{\prime \prime} \mathrm{W}$ (Property 1); São José do Calçado, with coordinates $20^{\circ} 5618.16^{\prime \prime} \mathrm{S}$ and $41^{\circ} 37 ' 53.04 "$ W (Property 2); and Jerônimo Monteiro, with coordinates $20^{\circ} 56^{\prime} 8.16^{\prime \prime} \mathrm{S}$ and $41^{\circ} 24 ' 33.12^{\prime \prime} \mathrm{W}$ (Property 3). The planted species was a hybrid of the Eucalyptus grandis and Eucalyptus urophylla species, spaced $3 \times 3$ meters apart, produced by vegetative propagation, with an average age of 6 years and approximately $180 \mathrm{~m}^{3} \cdot \mathrm{ha}^{-1}$. All plantations were located in sloping areas with a slope of approximately $35 \%$, where mechanized operations were not feasible.

The region's climate is Cwa mesothermal, with a rainy summer and dry winter according to the Köppen classification, with an average temperature in the hottest month of $22^{\circ} \mathrm{C}$. The average annual temperature is $20^{\circ} \mathrm{C}$ and the average annual rainfall for the region is 1,414 mm (CASTRO et al., 2010; PAIVA et al., 2010).

\section{Data collection}

The forest cutting operation included felling and processing (delimbing, topping and tracing) into logs of 2 meters on the three properties, which were carried out by an operator and a helper who assisted in the logging and stacking operations. Five chainsaws were analyzed on property 1, two on property 2 and two on property 3 , totaling 9 operators (all male aged 25 to 42 years) who handled the chainsaws during an 8-hour workday.

The research was approved by the Ethics Committee on Research with Humans at the Alegre Campus of UFES, registration number 80593017.3.0000.8151.

Portable accelerometers (model NK 300) were used to measure the vibration to which the operators were exposed, being positioned on the chainsaw at the measurement point located on the handgrip hand fitting between the specific glove for chainsaw operation and the handle point on the three axes evaluated, as described by FUNDACENTRO (2013) and shown in Figure 1.
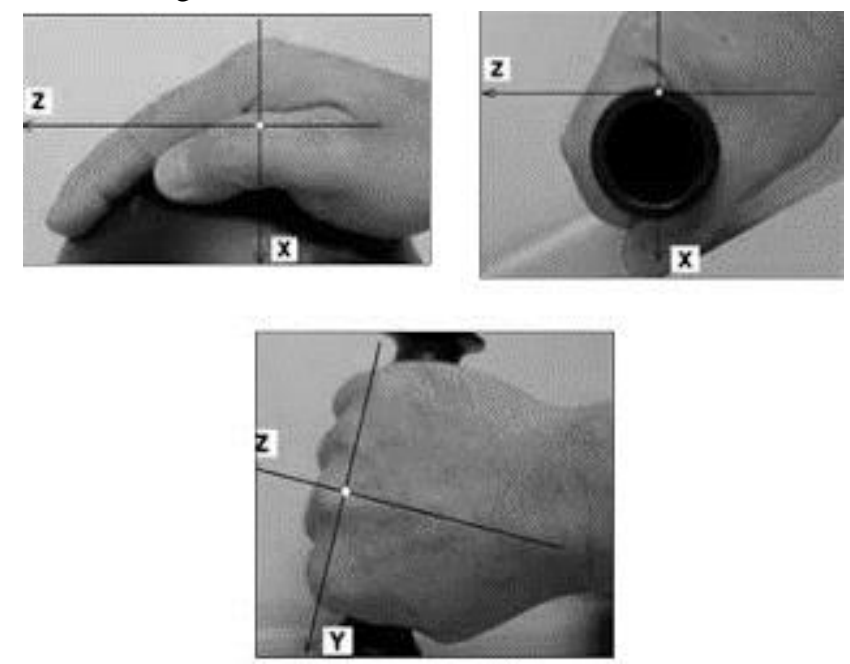

FLORESTA, Curitiba, PR, v. 50, n. 3, p. 1653 - 1659, jul/set 2020.

Jesus, A. T. et.al.

ISSN eletrônico 1982-4688

DOI: 10.5380/rf.v50 i3. 65530 
Figure 1. Evaluation axes for operators' hands and arms.

Figura 1. Eixos de avaliação para mãos e braços dos operadores.

The technical descriptions of the analyzed chainsaws are described in Table 1.

Table 1. Characteristics of chainsaws used in the study.

Tabela 1. Características das motosserras utilizadas na pesquisa.

\begin{tabular}{cr}
\hline Property & Description of chainsaws \\
\hline 1 & Two-stroke engine, 4.6 horsepower with $65.1 \mathrm{cc}$. \\
\hline 2 & Two-stroke engine, 4.6 horsepower, 59 cylinder capacity \\
\hline 3 & Two-stroke engine, 5.3 horsepower with 72.2 cylinder capacity \\
\hline Source: Manufacturers' Electronic Portal. &
\end{tabular}

Source: Manufacturers' Electronic Portal.

* All chainsaws analyzed were less than 5 years old and in good working order.

For the assessment of exposure limits, the methodology proposed by Occupational Hygiene Standards number 10 was used (FUNDACENTRO, 2013). This standard establishes the vibration limits for hands and arms based on the following equations:

$$
a m r=\sqrt{\left(f_{x} \times a m_{x}\right)^{2}+\left(f_{y} \times a m_{y}\right)^{2}+\left(f_{z} \times a m_{z}\right)^{2}}
$$

In which: $\mathrm{amr}=$ the resulting average acceleration; $\mathrm{am}=$ the average acceleration on the $\mathrm{x}, \mathrm{y}, \mathrm{z}$ axes $(\mathrm{ms}-2)$, ef $=$ the multiplication factor as a function of the considered axis ( $f=1$ for the three axes).

Next, the average partial exposure acceleration value (amep) was calculated from the amr, which corresponds to the vibration to which the operator is subjected in a given time interval, as shown in equation 2 :

$$
\text { amep }=\frac{1}{S} x \sum_{\mathrm{K}=1}^{\mathrm{S}} \mathrm{am}_{\mathrm{x}, \mathrm{y}, \mathrm{z}}
$$

In which: $\mathrm{am}=$ the mean acceleration on the $\mathrm{x}, \mathrm{y}, \mathrm{z}$ axes $(\mathrm{ms}-2)$; and $\mathrm{K}=$ the number of measured samples, ranging from 1 to $\mathrm{S}$ samples.

With the amep value, it was possible to subsequently calculate the acceleration resulting from partial exposure (arep), which corresponds to the square root of the mean acceleration squared to which the operator is exposed to, according to equation 3 :

$$
\operatorname{arep}=\sqrt{\operatorname{amep}_{\mathrm{x}}^{2+} \operatorname{amep}_{\mathrm{y}}^{2}+\operatorname{amep}_{\mathrm{z}}^{2}}
$$

In which: amep $=$ the mean acceleration of partial exposure $\left(\mathrm{ms}^{-2}\right)$.

The arep values enabled calculations to be performed to determine the acceleration resulting from daily occupational (are) exposure, considering the three occupational axes according to equation 4 :

$$
\text { are }=\sqrt{\frac{1}{T} x \sum_{i=1}^{m} n_{i} x \operatorname{arep}^{2} x T_{i}}
$$

In which: arep $=$ the acceleration resulting from partial exposure $\left(\mathrm{ms}^{-2}\right)$; ni $=$ the number of repetitions of the acceleration component in the working day; $\mathrm{Ti}=$ the duration of the exposure component; $\mathrm{m}=$ the number of components of exposure which make up the daily journey; and $\mathrm{T}=$ the daily working time. 
Finally, the acceleration value resulting from normalized exposure (aren) was calculated using equation

$$
\operatorname{aren}=\operatorname{are} \sqrt{\frac{T}{T_{0}}}
$$

In which: Are $=$ the acceleration resulting from exposure $\left(\mathrm{ms}^{-2}\right) ;$ To $=$ the exposure time of the operator to vibration; and $\mathrm{T}=$ the daily working time $(480 \mathrm{~min})$.

The vibration limits established in the NHO-10 Standard provide for an acceleration value resulting from normalized exposure (aren) of $2.5 \mathrm{~ms}^{-2}$ and the maximum exposure limit of $5.0 \mathrm{~ms}^{-2}$. The calculations for determining the acceleration were performed for both hands of the operators to identify possible differences in the perception of hand vibration during the activity.

In the study it was observed that all the operators involved are right-handed. This makes their posture when wielding the chainsaw to follow the pattern shown in Figure 2, in which the operator's right hand accelerates the machine and the left hand handles the machine when cutting.

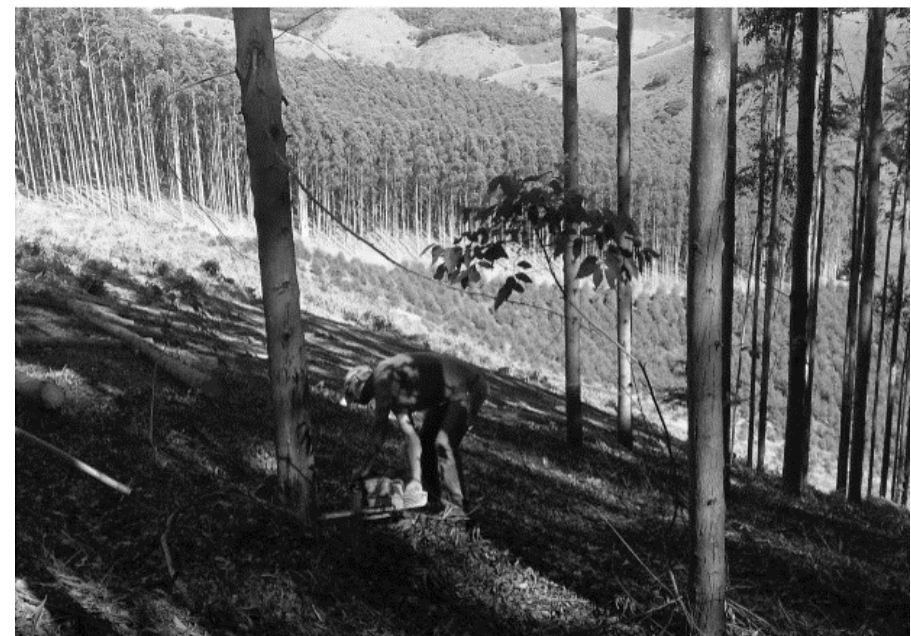

Figure 2: Position of the operators' hands at the time of cutting.

Figura 2: Posição das mãos dos operadores no momento do corte.

Source: The author.

\section{Statistical procedures}

A confidence interval was calculated at the level of $5 \%$ probability of error for exposure to vibration to determine possible differences between the pairs of averages of the properties under study, according to equation 6:

$$
\operatorname{IC}\left(\mu_{\mathrm{i}}-\mu_{\mathrm{j}}\right)_{1-\alpha}=\bar{y}_{\mathrm{i}}-\bar{y}_{\mathrm{j}} \pm \frac{\mathrm{t}_{\alpha}}{2} \times\left(\frac{\sigma_{\mathrm{i}}}{\sqrt{\mathrm{n}}}-\frac{\sigma_{\mathrm{j}}}{\sqrt{\mathrm{n}}}\right)
$$

In which: $\mathrm{CI}=$ Confidence interval; $\overline{\mathrm{y}} \mathrm{i}=$ Sample average of the properties under study; $\mathrm{T} \alpha=\mathrm{Student}$ 's t-value at the $5 \%$ error probability level; and $\sigma=$ sample standard deviation of the properties under study.

The presence or absence of the number was observed as zero within the ranges to infer if there were significant statistical differences between the pairs of vibration averages between the harvesting teams measured in the properties from the confidence interval by the Tukey test at the $5 \%$ error probability level. If present, it implies that the averages do not differ statistically; if not present, the means differ statistically from each other.

The use of the confidence interval is necessary to perform the comparison of means, since the low number of operators and the difficulty in homogenizing properties make it difficult to use other comparison analyses of control means. 


\section{RESULTS}

Table 2 shows the data for measuring the average acceleration on all machines evaluated on the three axes (X, Y and $\mathrm{Z}$ ). The results of the acceleration values are also shown, as well as the average vibration that the operators may be exposed to in the right and left hand grooves.

Table 2. Average exposure to vibration.

Tabela 2. Exposição media à vibração no encaixe das mãos.

\begin{tabular}{|c|c|c|c|c|c|c|c|}
\hline \multirow{2}{*}{ Rated Hand } & \multirow{2}{*}{ Operator } & \multicolumn{3}{|c|}{ Rated axis $\left(\mathrm{ms}^{2}{ }^{2}\right)$} & \multirow{2}{*}{ Arep $\left(\mathrm{ms}^{-2}\right)$} & \multirow{2}{*}{$\operatorname{Are}\left(\mathrm{ms}^{-2}\right)$} & \multirow{2}{*}{ Aren $\left(\mathrm{ms}^{-2}\right)$} \\
\hline & & $\operatorname{amx}$ & amy & $\mathrm{amz}$ & & & \\
\hline Right & \multirow{2}{*}{1} & 2.18 & 1.88 & 1.51 & 3.24 & 1.87 & 1.98 \\
\hline Left & & 3.49 & 3.82 & 3.93 & 6.49 & 3.74 & 3.96 \\
\hline Right & \multirow{2}{*}{2} & 2.79 & 2.72 & 2.36 & 4.55 & 2.62 & 2.77 \\
\hline Left & & 7.43 & 5.81 & 6.15 & 11.25 & 6.49 & 6.87 \\
\hline Right & \multirow{2}{*}{3} & 3.13 & 2.19 & 2.75 & 4.70 & 2.71 & 2.78 \\
\hline Left & & 4.09 & 3.72 & 2.81 & 6.20 & 3.57 & 2.87 \\
\hline Right & \multirow{2}{*}{4} & 2.67 & 2.09 & 1.82 & 3.84 & 2.21 & 2.34 \\
\hline Left & & 3.06 & 3.43 & 3.44 & 5.74 & 3.31 & 3.50 \\
\hline Right & \multirow{2}{*}{5} & 4.06 & 3.33 & 2.56 & 5.84 & 3.37 & 3.57 \\
\hline Left & & 5.68 & 6.09 & 5.93 & 10.22 & 5.90 & 6.25 \\
\hline Right & \multirow{2}{*}{6} & 2.90 & 2.85 & 2.25 & 4.27 & 2.43 & 2.57 \\
\hline Left & & 2.98 & 2.28 & 1.99 & 4.24 & 2.44 & 2.58 \\
\hline Right & \multirow{2}{*}{7} & 4.35 & 3.69 & 2.96 & 6.42 & 3.70 & 3.92 \\
\hline Left & & 6.88 & 5.39 & 4.49 & 9.82 & 5.66 & 5.99 \\
\hline Right & \multirow{2}{*}{8} & 2.44 & 2.05 & 1.69 & 1.80 & 2.11 & 2.99 \\
\hline Left & & 2.98 & 2.57 & 2.52 & 1.97 & 2.20 & 3.12 \\
\hline Right & \multirow{2}{*}{9} & 2.45 & 2.1 & 1.73 & 3.30 & 2.18 & 3.08 \\
\hline Left & & 3.01 & 2.44 & 2.79 & 4.60 & 2.85 & 4.27 \\
\hline
\end{tabular}

The acceleration values resulting from the normalized exposure (aren) observed in the fitting of the operators right hand are smaller in all cases than those observed in the left hand. However, even though the operators' right hand received the least vibration action, it is possible to observe that about $67 \%$ of the operators act with vibration above the action level of $2.5 \mathrm{~ms}^{-2}$ recommended by NHO-10. Only $22 \%$ operate within the permitted limits, and $11 \%$ are at an intermediate vibration level.

None of the evaluated operators had vibration exposure above $5 \mathrm{~ms}^{-2}$ for the right hand. There is consequently no need to adopt urgent control measures to reduce vibration in the operator's right hand seat. However, when evaluating the left hand, it is observed that the values are above the acceptable exposure limits for all analyzes.

The evaluation of the operators' left hand shows that the exposure degree to vibration is worrying, since about $45 \%$ of operators are above the recommended action level; $22 \%$ operate in the intermediate exposure region; and $33 \%$ operate above acceptable exposure limits, making immediate measures necessary such as alternating semi-mechanized activities for manual and periodic maintenance of chainsaws in order to decrease the intensity and exposure time of operators.

For the average vibration received in the fittings of the operators' right and left hands, it was possible to observe that none of the operators operate within the recommended limit of up to $2.5 \mathrm{~ms}^{-2}$ and none above the maximum exposure limit of $5 \mathrm{~ms}^{-2}$. However, 55\% of these operators carry out their activities with an acceleration which varies from $2.5 \mathrm{~ms}^{-2}$ to $3.5 \mathrm{~ms}^{-2}$ (exposure above the indicated action level). The remaining $45 \%$ carry out their activities in the acceleration range from $3.5 \mathrm{~ms}^{-2}$ to $5 \mathrm{~ms}^{-2}$ (intermediate exposure to vibration).

Table 3 presents the statistical analysis results by the confidence interval method at the $5 \%$ error probability level, where the comparison was performed for the average obtained from the exposure to vibration in both hands of the operator. The identical letters presented indicate that it was not possible to observe the existence of significant differences between the evaluated averages.

FLORESTA, Curitiba, PR, v. 50, n. 3, p. 1653 - 1659, jul/set 2020

Jesus, A. T. et.al. 
Table 3: Means comparison by confidence interval at the 5\% significance level for the Tukey test. Tabela 3: Comparação de médias por intervalos de confiança ao nível de 5\% de probabilidade de erro pelo teste Tukey.

\begin{tabular}{|c|c|c|c|}
\hline Property & Operator & Average $\mathrm{ms}^{-2}$ & Tukey \\
\hline \multirow{5}{*}{1} & 1 & 2.97 & B \\
\hline & 2 & 4.82 & Ç \\
\hline & 3 & 2.83 & B \\
\hline & 4 & 2.92 & B \\
\hline & 5 & 4.91 & Ç \\
\hline \multirow{2}{*}{2} & 6 & 2.58 & THE \\
\hline & 7 & 4.96 & Ç \\
\hline \multirow{2}{*}{3} & 8 & 3.06 & B \\
\hline & 9 & 3.68 & B \\
\hline
\end{tabular}

\section{DISCUSSION}

It is generally observed that the operators' exposure to vibration is above the level of action established by the rules, especially in relation to the left hand. Thus, there is a need for changes, such as switching from semimechanized to manual activities (manual tipping and stacking) during their activities in order to improve the working conditions of operators to reduce exposure.

A possible explanation for the lower vibration values in the operator's right hand socket may be due to the fact of the greater distance between the worker's right hand and the chainsaw's contact point with the trees to be felled and the machine's motor, since all operators are right-handed and use their right hand to start the chainsaws.

However, although the right hand receives less vibration, preventive and/or corrective measures are needed which can contribute to reducing the exposure of operators to vibration from the machines used in their workday. Among such measures, Cunha (2018) recommends care with the maintenance and sharpening of the chain so that friction with the trees to be felled is reduced, replacement of the machines when it is detected that they have reached their useful life or reduced operator exposure time.

Because the three properties have a helper for logging and stacking operations, a rotation of activities among workers is proposed to reduce the exposure time to vibration by chainsaw operators, with no damage to their productivity during the working day. This is possible through adequate training and qualification of helpers in the safe and productive handling of chainsaws used during harvesting.

It was possible to observe from Table 3 that operators 7, 5 and 2 are most exposed to vibration. The greater exposure of these workers can be related to less attention in the maintenance of the machines and the shock absorber system, since it is noted that these machines have the lowest power among those which have been evaluated when observing the description of such machines present in Table 1.

From the results presented in this study, it is observed that the risk to which chainsaw operators are exposed in the evaluated properties is especially evidenced by the great exposure of workers throughout their working hours. This risk is even more worrying when we extrapolate the duration of the workday by the time that these operators exercise this profession (KAYSER et al., 2009).

According to Mendes, (2019), periodic maintenance and adjustments must be carried out to reduce the vibration emitted by the chainsaw replacing worn, damaged and defective parts. According to Leão (2005), continuous exposure should be prevented with pauses of 10 minutes per hour of continuous exposure to mitigate negative effects of exposure to vibrations.

There is a gradual degeneration of vascular and nerve tissue in forestry workers who use chainsaws, causing loss of manipulative capacity and tact in the hands, making motor control difficult (IIDA, 2016). In this sense, this study is important to suggest changes in the operators' behavior when improving the maintenance conditions of their machines; and changes related to the work environment, so that the owners of the evaluated areas must change the chainsaws when they reach a certain time of use. In addition, the most significant change which should occur within the work environment is a rotation between operators and helpers with due training provided to the latter.

FLORESTA, Curitiba, PR, v. 50, n. 3, p. 1653 - 1659, jul/set 2020.

Jesus, A. T. et.al. 


\section{CONCLUSIONS}

- The operators of the semi-mechanized forest harvesting in the evaluated properties operate at vibration levels above the limits recommended by the Legislation for the left hand, creating the need for preventive measures.

- The left hand fitting of the operators receives greater vibration from the chainsaws due to the positioning in relation to the contact point of the chainsaw's teeth with the trees to be felled and with the machinery.

- There is a need to take preventive measures capable of reducing the effects of vibration on the operators' bodies; such measures can be preventive or corrective, ranging from the maintenance of the machines to training the helpers to perform a rotation of activities. In addition, the need to reduce exposure time should be assessed.

\section{REFERENCES}

CANADIAN CENTRE FOR OCCUPATIONAL HEALTH AND SAFETY - CCOHS. Vibration $<$ http://search.ccinfoweb.ccohs.ca/ccohs/jsp/search/ccohs.jsp?QueryText=vibration\&MaxDocs=500\&ResultStart $=1 \&$ SortSpec $=$ Score + desc $\&$ hTab $=0 \&$ wb-srch-sub $>$. Acesso em: 05 mai. 2018.

CUNHA, I. A., YAMASHITA, R. Y., CORRÊA, I. M., MAZIERO, J. V. G, MACIEL, A. J. S. Avaliação de ruído e vibração em motosserra: resultados parciais. Bragantia, Campinas, v. 57, n. 1, p.,1998 .

FIEDLER, N. C.; MARIN, H. B.; OLIVEIRA, J. T. S.; CARMO, F. C. A. Análise da vibração no processamento secundário de madeiras com diferentes massas específicas aparentes. Floresta, v. 43, p. 1-8, 2013.

FUNDACENTRO: Avaliação da exposição ocupacional a vibrações de mãos e braços: Norma de Higiene Ocupacional- 10. Procedimento técnico. São Paulo- SP. 2013.

IIDA, I. Ergonomia: projeto e produção. São Paulo: Editora Edgar Blücher Ltda, 2016.

KAYSER, C.; CORRÊA, M. J. U.; ANDRADE, L. E. C.; Fenômeno de Raynaud. Revista Brasileira de Reumatologia, São Paulo- SP. v.49. n.1, p 48-63, 2009.

MENDES, L. T.; FIEDLER, N. C.; BERUDE, L. C.; CARMO, F. C.A; JUVANHOL, R. S; NOGUEIRA, D. F. B. Análise da vibração mão-braço na colheita florestal semimecanizada. Agropecuária Científica no semi-árido, v. 15, p. $35,2019$.

NESI, M. Identificação dos riscos associados ao corte semimecanizado de eucalipto e pinus na exploração florestal. 2011. 57 f. Monografia (Especialização em Engenharia de Segurança do Trabalho) - Programa de Pós-graduação da Universidade do Extremo Sul Catarinense. Criciúma, 2011

NUNES, I. L. A importância da avaliação de factores de risco ocupacionais em políticas de aquisição de equipamentos. $\mathbf{O}$ caso da exposição à vibração. Proceedings das $3^{\mathrm{a}}$ Jornadas Técnicas de Engenharia Logística Militar-O ciclo de vida dos materiais, organizada pelo Exército Português, Paço de Arcos, CDRom, 2005

OTERO, M. I.; ROMERO, M. P.; GONZÁLES, R. B.; VICTORIA, M. A. V. Mentifedato y fenómeno de Raynaud secundário. Senegem- Medicina familia. Vallodolid, Spain. v.39, n. 6, p. 330-334. 2013.

SANT'ANNA, C. M.; MALINOVISK, J. R.; PIOVESAN, A. Estudo do perfil físico adequado de operadores de motoserra para o corte de eucalipto em região montanhosa. Cerne, Lavras, MG. v. 6, n. 2, p. 95-103, 2000.

VICENTE, E. O; REDONDO, M. G. Raynaud's phenomenon in children. Reumatología Clínica. Valladolid, Spain. 2015. Disponível em http://www.sciencedirect.com/science/article/pii/S2173574316300843> acesso: 6 de mai de 2018. 